ZOOLOGIA 29 (6): 557-562, December, 2012

Available online at www.scielo.br/zool

\title{
Seven new species of Cerambycidae (Coleoptera) from South America with the proposal of three new genera
}

\author{
Ubirajara R. Martins ${ }^{1} \&$ Maria Helena M. Galileo²
}

\begin{abstract}
${ }^{1}$ Museu de Zoologia, Universidade de São Paulo. Caixa Postal 42494, 04218-970 São Paulo, SP, Brazil. urmsouza@usp.br ${ }_{2}^{2}$ Museu de Ciências Naturais, Fundação Zoobotânica do Rio Grande do Sul. Caixa Postal 1188, 90001 -970 Porto Alegre, RS, Brazil.galileo@fzb.rs.gov.br
\end{abstract}

\begin{abstract}
The following new species are described - Cerambycinae, Sydacini: Sydax flechtmanni sp. nov. from Brazil (São Paulo); Eburiini: Ebrodacrys biffipradorum sp. nov. from Brazil (Roraima); - Lamiinae, Pteropliini: Ataxia piauiensis sp. nov. from Brazil (Piuaî); Calliini: Amucallia carbonaria sp. nov. from French Guiana; A. citrina sp. nov. from Guiana. Also in Lamiinae, two new genera of Onciderini are proposed. Ubytyra gen. nov., type species U. tuberosa sp. nov. from Peru (Junin) e Japi gen. nov., type species J. duartei sp. nov., from Brazil (São Paulo); Ubytyra gen. nov. can be distinguished by the sides of prothorax with long central spine rounded at apex, and this new feature among Onciderini is discussed. Japi gen. nov., is characterized by a fringe of long hairs on the inner side of antennomere III, present only in species from North and Central America, and gender comparison of these species is done and discussed. In Hemilophini, Pseudotacocha gen. nov., type species P. magnifica sp. nov. from Peru (Cuzco), are described. The new genera can be distinguished by eyes well developed, elytra with two carinae and the apices outer with short spine; a comparison with related genera is done. KEY WORDS. Calliini; Eburiini; Hemilophini; Onciderini; Sydacini.
\end{abstract}

Based on material from various collections, new species within the Cerambycinae (Eburiini and Sydacini) and Lamiinae (Pteropliini, Onciderini, Hemilophini, and Calliini) are described and illustrated. In Onciderini, we describe two new genera. Only the tribes Eburiini and Sydacini were revised by Martins $(1999,2003)$.

The type material belongs to the following institutions: American Coleoptera Museum, San Antonio (ACMS); Museu de Ciências Naturais, Fundação Zoobotânica do Rio Grande do Sul, Porto Alegre (MCNZ); Museu de Zoologia, Universidade de São Paulo, São Paulo (MZUSP); Departamento de Proteção de Plantas, Universidade Estadual Paulista, Campus de Ilha Solteira (UNESP); National Museum of Natural History, Washington (USNM). The measurements are provided in millimeters $(\mathrm{mm})$.

\section{TAXONOMY}

\section{Cerambycinae \\ Sydax flechtmanni sp. nov.}

Fig. 1

Head brown-reddish or brownish. Frons not swollen. Antenniferous tubercles contiguous basally. Upper ocular lobes with five rows of ommatidia, distance between lobes twice as long as width of a lobe. Antennae of males reaching elytral apices almost at apex of antennomere VII; of females, at middle of antennomere IX. Scape brownish with surface slightly ir- regular (25x), particularly on outer side. Antennomere III brownish, less swollen than in Sydax stramineus. Prothorax brownish, narrower at basal third. Pronotum pubescent, thin, densely microsculptured (40x). Lateral sides of prothorax similarly sculptured. Prosternum medially smooth. Elytra yellowish and translucent, with brownish longitudinal stripe starting at humeri; apices acuminate. Femora brownish on club and yellowish on pedunculus. Tibiae yellowish. Thoracic sterna reddish-brown. Abdomen brownish.

Measurements male/female, respectively. Total length, 10.0-12.0/9.5-12.4; prothorax length, 2.1-2.7/1.8-2.2; widest width of prothorax, 1.1-1.5/1.0-1.4; length of elytron, 6.7-8.8/ 6.7-9.0; humeral width, 1.6-1.9/1.5-2.0.

Type material. Holotype male, Brazil, São Paulo: Guzolândia (Fazenda Ezuto, 20³7'06"S, 50³8"8,83"W), H. A.S. Silva leg., "Ex trunc of diseased 6-yr old clone RRIM600 Hevea brasilensis." (MZUSP). Paratypes - same data as holotype, 5 males, 5 females ( 2 males, 2 females, MZUSP; 1 male, 1 female, MCNZ; 2 males, 2 females, UNESP).

Etymology. The specific epithet honors Carlos Flechtmann (UNESP), who sent the type material for study.

Remarks. Martins (2003) revised the tribe Sydacini and provided a key to the identification of the species of Sydax Lacordaire, 1869. Sydax flechtmanni keys out to couplet four, along with S. stramineus Lacordaire, 1869 and S. gibbus Joly, 1985. Sydax flechtmanni can be distinguished from S. gibbus as follows: in males the frons is not swollen, the scape has no rugosities on 
the outer side, and the ocular lobes are distant from each other. Sydax flechtmanni is more similar to $S$. stramineus, differing by: brownish coloration of head, scape, prothorax, ventral surface of body and clubs of femora; antenniferous tubercles approximated basally; upper ocular lobes with five rows of ommatidia; antennomere III of males less swollen (Fig. 1); and elytra translucent. In $S$. stramineus the body is orange; the antenniferous tubercles are separated basally; the upper ocular lobes have four rows of ommatidia; the antennomere III of males is more swollen; and the elytra are less or not translucent.

\section{Eburodacrys biffipradorum sp. nov.}

Fig. 2

Integument orange-reddish. Vertex finely punctuate. Upper ocular lobes with six rows of ommatidia. Apex of antennomere VII reaching apices of elytra in males. Scape gradually thickened toward apex, shallowly punctuated. Hairs on inner side of antennomere III short and more concentrated on apical half. Sides of prothorax with lateral, central, concolorous, short spine, and short black spot near anterior margin; lateroanterior tubercle discrete. Pronotum with two black anterior tubercles; behind them two black, elongate spots not reaching basal edge; entire pronotal surface with irregular wrinkles, including tubercles. Mesosternum without tubercle. Each elytron with three ivory spots: first one basal, as broad as distance between spot and scutellum, and followed by small black mark; second and third ones median elliptical, not contiguous but very close to each other, surrounded with black; outer spot beginning at middle of inner spot. Black triangular spot anterior to black spines. Epipleura with teeth near base of elytron, yellowish on anterior 2/3. Punctuation more concentrated at anterior half, without rough punctures. Profemora entirely orange. Meso- and metafemora orange with apices and inner spines black. Tibiae and tarsi orange.

Measurements holotype male. Total length, 14.4; length of prothorax, 3.0; greatest width of prothorax, 3.0; length of elytron, 9.9; humeral width, 3.3.

Type material. Holotype male, Brazil, Roraima: Caracaraí (Vila Caicubi, trilha Paraguai, $0^{\circ} 56^{\prime} 58,7^{\prime \prime} \mathrm{S}, 62^{\circ} 07^{\prime} 57,4^{\prime \prime} \mathrm{W}$ ), 30.VIII-11.IX.2011, G. Biffi \& L.R. Prado leg., Malaise 2 (MZUSP).

Etymology. The species epithet honors Laura R. Prado and Gabriel Biffi, who collected the holotype.

Remarks. Eburodacrys biffipradorum sp. nov. is similar to E. prolixa Monné \& Martins, 1992, described from Rondônia, and E. pinima Martins, 1999, from Pará, due to the following features: spines at the sides of prothorax shorter than pedicel; punctures of pronotum intermixed by wrinkles on the sides; median elytral ivory spots: inner spot elliptical, outer one also elliptical, beginning at mid length of inner spot (MARTINs 1999', key to species, dilemma 63).

The new species differs from E. prolixa by the concolorous lateral spine of the prothorax with general integument; the pres- ence of black spots behind pronotal tubercles. In E. prolixa, the lateral spine of prothorax is black and the pronotum does not have a black spot behind tubercles. Eburodacrys biffipradorum differs from E. pinima by the following features: absence of a circular black spot on vertex; prothorax as wide as long with concolorous lateral spine; presence of black spots behind pronotal tubercles; shorter and more rounded ivory spots on elytra; and the apices of meso- and metafemora darkened with black spines. In E. pinima there is a circular black spot on the vertex; the prothorax is wider than long, with lateral spine black; the pronotal tubercles do not have a black spot posteriorly; the ivory spots of the elytra are narrower and more elongated, and the spines on the apices of the meso- and metafemora are orange-reddish.

\section{Lamiinae Onciderini Ubytyra gen. nov.}

Type-species, Ubytyra tuberosa sp. nov.

Frons slightly longer than wide. Upper ocular lobes with six rows of ommatidia, separated by twice the width of a lobe. Lower ocular lobes longer than genae. Antenniferous tubercles projected. Antennae reaching elytral apices, approximately at apex of antennomere IX. Scape with moderate club, as long as half of antennomere III, without apical scar. Antennomere III bisinuate. Antennomeres IV-XI decreasing in length. Prothorax wider than long (including lateral spines). Sides of prothorax with long central spine rounded at apex and directed upward. Pronotum with five gibbosities, slightly prominent: one central, situated behind all others; two on each side, posterior one transversal. Elytra with small granules approximately up to anterior fifth, more concentrated behind humeri; two inconspicuous central-basal gibbosities. Femora pedunculate and clavate. Tarsal claws divergent. Basal half of tarsomeres $\mathrm{V}$ with pale tegument.

Etymology. Tupi, ubytyra $=$ mount, alluding to the lateral tubercles of prothorax. Gender feminine.

Remarks. The presence of long spines at the middle sides of the prothorax in Ubytyra gen. nov., a new feature among the Onciderini, led us to think that the genus might belong in another tribe with divergent tarsal claws. A few other characters, however, led us to consider it to be a member of the Onciderini: antennomere III bisinuate; presence of granules at base of elytra; tarsomeres V with pale tegument on basal half. The prothoracic lateral tubercles are inconspicuous, shorter than pedicel and usually located on the basal third.

Some species of Tulcus Dillon \& Dillon, 1945 have very inconspicuous gibbosities at the sides of prothorax, antennomere III bisinuate, and tegument of tarsomeres V pale. Ubytyra gen. nov. can be distinguished from Tulcus particularly by the developed lateral spine at the middle of the prothorax and the presence of granules at base of elytra. In Tulcus, the tubercles at the prothorax are very inconspicuous and located near the base, and the elytral punctuation is not granulated. 


\section{Ubytyra tuberosa sp. nov.}

Fig. 3

Integument black. Central frontal region with yellowish sparse pubescence. Vertex and post-ocular regions with yellowish pubescence, variegated with brown. Scape, pedicel, and basal half of antennomere III with yellowish pubescence variegated with brown. Apical half of antennomere III with brownish pubescent. Antennomeres IV-XI black, except base of antennomeres IV, VI, and VIII with yellowish ring. Prothorax covered with yellowish pubescence variegated with brown, apices of tubercles glabrous. Elytra with pubescence predominantly brown, with few small irregular areas covered with yellowish pubescence. Basal fifth of elytra with small tubercles, more concentrated behind humeri, where they are followed by rough punctures; elytral punctuation moderately dense with small glabrous spots. Femora, tibiae, and tarsomeres I-III covered with brown pubescence variegated with abundant, small white setae. Tarsomere $\mathrm{V}$ with tegument yellow on basal $2 / 3$ and black at apical third. Ventral surface of body clothed with yellowish pubescence variegated with brown.

Measurements holotype female. Total length, 17.9; prothorax: length, 3.0; greatest width (including lateral spines), 4.8; elytron: length, 13.0; humeral width, 7.0; frons: length, 2.5; width, 2.2; lower ocular lobes length, 1.1; genae length, 0.9; scape length, 2.5; antennomere III length, 3.9.

Type material. Holotype female, Peru, Junin: Pampa Hermosa Lodge near San Ramon, 1220 m, 3-5.XII.2008, J. Hepner leg. (ACMS).

Etymology. Latin, tuberosus = with several prominences; alluding to the small tubercles at base of elytra.

\section{Japi gen. nov.}

Type-species, Japi duartei sp. nov.

Frons as long as wide; upper ocular lobes with six rows of ommatidia separated by twice the width of a lobe. Lower ocular lobes longer than genae. Antenniferous tubercles projected and separated. Antennae (male) reaching apices of elytra at base of antennomere VII. Scape subcylindrical, slightly swollen toward apex and barely longer than antennomere III, lacking apical scar. Antennomere III straight with a fringe of dense hairs on inner side denser toward apex. Antennomeres IV-XI decreasing in length. Prothorax wider than long. Sides of prothorax with glabrous tubercle at basal third. Pronotum with five glabrous spots: one median, a little behind all others, and two on each side, outer ones behind inner ones. Elytra with small granules at anterior third. Elytral apices rounded. Femora pedunculate-clavate. Apex of metafemora reaching middle of urosternite II. Tibiae shorter than femora. Tarsomere V with tegument unicolor.

Etymology. Tupi, japi = bird of the family Icteridae and name of the mountain where the holotype was collected. Gender feminine.
Remarks. Japi gen. nov. is characterized by a fringe of long hairs on the inner side of antennomere III. Species in genera that have similar pilosity are all from North and Central America: Periergates Lacordaire, 1872 with three species from Mexico and Central America; Taricanus Thomson, 1868 with two species from Mexico and Nicaragua, and Microcanus Dillon \& Dillon, 1945 with only one species found in Mexico. Species of Periergates, Microcanus, and Taricanus have orange, small and circular spots on the elytra, similar to those of Japi duartei. However, Japi differs by having the pronotum without wrinkles and with five glabrous spots. In Periergates and Taricanus the pronotum is transversally wrinkled and without glabrous spots. It can be separated from Microcanus by the antennomere III, which is not swollen apically; antennomere IV without dense hairs, and prothorax with five glabrous spots.

\section{Japi duartei sp. nov.}

Fig. 4

Integument black or dark-brown; antennae, tibiae, and tarsi reddish; femora reddish and black beneath. Frons with sparse orange pubescence; pubescent stripes orange, dense, on either side, on inner edge of eyes extended up to upper ocular lobes. Vertex with few punctures between upper ocular lobes. Scape densely pubescent. Sides of prothorax and pronotum covered with sparse orange pubescence, more concentrated along the five glabrous, black pronotal spots. Elytra covered with orange pubescence intercalated with circular spots of dense orange pubescence, irregularly disposed throughout surface; basal third covered with small granules followed up to the apices by abundant glabrous spots. Ventral surface covered with whitish pubescence; metasternum medially white, laterally with pubescent spot.

Measurements holotype male. Total length, 19.7; prothorax: length, 2.2, greatest width, 1.6; elytron: length, 7.9, humeral width, 3.2; frons: length, 1.3, width, 1.3; lower ocular lobes length, 0.9; genae length, 0.6; scape length, 2.0; antenomere III length, 2.3.

Type material. Holotype male. Brazil, São Paulo: Jundiaí (Base Ecológica Serra do Japi, 2314'53"S, 4657’26,1"W), 24.II.2012, Expedição Lepidopterológica do Museu de Zoologia leg. (MZUSP). Paratype, female, same locality and collector as holotype, 20-22.XII.2011 (MZUSP).

Etymology. The species name honors Marcelo Duarte da Silva, who leaded the MZUSP Lepidoptera Expedition and collected the holotype.

\section{Pteropliini \\ Ataxia piauiensis sp. nov.}

Fig. 5

Integument brown. Head covered with yellowish pubescence. Frons with sparse punctures among pubescence. Antennae almost reaching elytral apices; antennae of females shorter, 

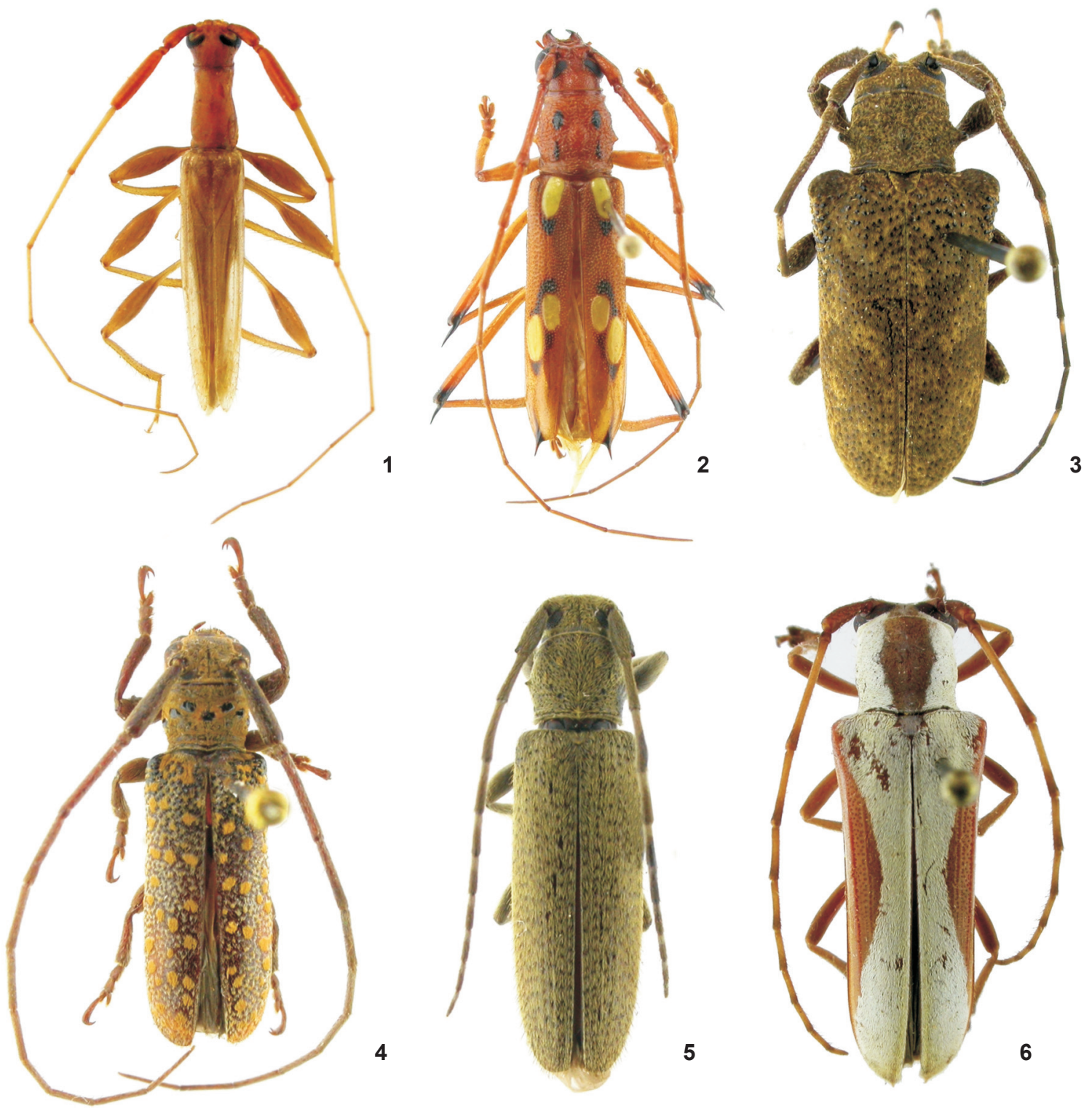

4
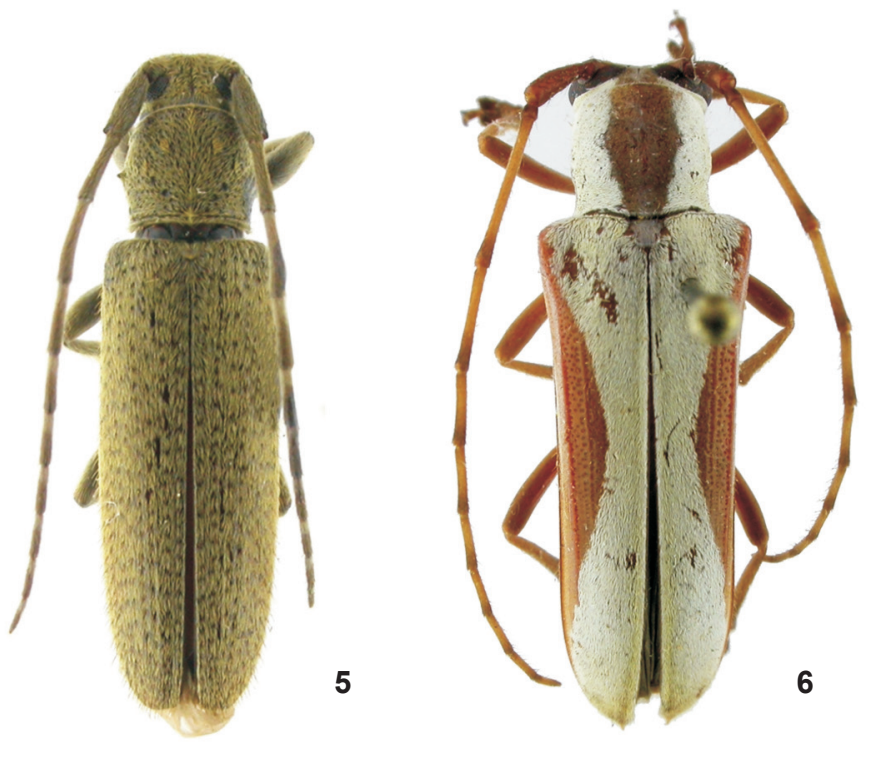

Figures 1-6. (1) Sydax flechtmanni sp. nov., holotype male, total length, $12.3 \mathrm{~mm}$; (2) Eburodacrys biffipradorum sp. nov., holotype male, total length,14.4 mm; (3) Ubytyra tuberosa sp. nov., holotype female, total length, $17.9 \mathrm{~mm}$; (4) Japi duartei sp. nov., holotype male, total length, $19.7 \mathrm{~mm}$; (5) Ataxia piauiensis sp. nov., holotype female, total length, $11.0 \mathrm{~mm}$; (6) Pseudotacocha magnifica sp. nov., holotype female, total length $20.5 \mathrm{~mm}$.

reaching apical fifth of elytra. Scape not punctate. Antennomere III brown, in females covered with yellowish pilosity; in males with whitish pubescence at base. Antennomeres IV-XI with pubescence whitish at base and brownish at apex. Prothorax with short lateral spine. Pronotum covered with yellowish pubescence interspersed with moderately dense punctures. Sides of prothorax punctuated. Thoracic sterna with yellowish pubescence, lacking contrasting punctures. Elytra with yellowish pubescence interspersed with relatively dense punctures. Elytral apices rounded and unarmed. Legs covered with yellowish pubescence. Femora with pubescence not interspersed with punctures. Urosternites with punctures more concentrated laterally. Measurements respectively male/female. Total length, 8.2/10.3-11.0; prothorax length, 1.6/2.0-2.1, greatest width of prothorax, 1.7/2.5-2.6; elytron length, 6.0/7.7-8.5; humeral width, 2.0/2.7-2.8. 
Type material. Female holotype, Brazil, Piauí: Bom Jesús (Fazenda Alto da Cruz, 906'41.3"S, 4422'32.75"W), 16.IV.2011, J.M. Araujo leg., "hyperxorophytic caatinga fragment, etanolbaited FIT" (MZUSP). Paratypes, same locality as holotype: male, 21.V.2011 (MZUSP); female, 28.V.2011 (UNESP).

Etymology. Epithet alludes to the Brazilian state of the type-locality.

Remarks. The following South American species of Ataxia have unarmed elytral apices and a short lateral spine on the prothorax: A. obtusa (Bates, 1866) and A. cineracea Galileo \& Martins, 2007. Ataxia obtusa has integument brown-reddish and prothorax densely punctuated. Ataxia piauiensis sp. nov. is more similar to A. cineracea (GaLileo \& Martins 2007: 205, fig. 4), which occurs in Bolivia and is distinguished by the non-punctate vertex and pronotum, and elytra with moderately dense and smaller punctures.

\section{Hemilophini \\ Pseudotacocha gen. nov.}

Type-species, Pseudotacocha magnifica sp. nov.

Frons unarmed (female). Eyes well developed. Upper ocular lobes with about 15 rows of ommatidia, separated by the width of a lobe. Lower ocular lobes large, three times as long as genae. Antennae with 11 segments; flagellomeres without tufts of hairs and not swollen; in females, almost reaching apices of elytra. Scape cylindrical, one third the length of antennomere III. Antennomere III with fringe of short and sparse hairs beneath. Antennomere IV approximately as long as scape. Remaining antennomeres decreasing in length. Prothorax almost as long as wide, with basal constriction more conspicuous than anterior one, and with very inconspicuous lateral gibbosity little behind middle. Pronotum regularly convex. Mesosternum depressed medially; mesosternal process prominent. Elytra elongated, apices with short outer spine; each with two carinae: one humeral, very conspicuous; another less visible, separated from the first. Femora subcylindrical. Apices of metafemora reaching urosternite III. Inner tooth of tarsal claws as long as outer. Urosternite V clearly emarginated centrally.

Etymology. Greek, pseudo = false; Tacocha = generic name. Feminine gender.

Remarks. Only one genus in Hemilophini, Phoebemima Tippmann, 1960, has eyes as developed as in the Aerenicini. Pseudotacocha gen. nov. differs from Phoebemima by the elytra with two carinae and the apices with outer short spine. In Phoebemima, the elytra do not have carinae and the apices are rounded and unarmed.

\section{Pseudotacocha magnifica sp. nov.} Fig. 6

Head with reddish integument; areas behind eyes covered with chalk white pubescence. Frons with very fine and sparse white pubescence. Anterior portion of vertex with few punctures. Scape, pedicel, and antennomere XI reddish. Antennomeres III-X yellowish with reddish tips. Longitudinal center of pronotum reddish, moderately punctuated; each side of pronotum clothed with wide stripe of chalk white, dense pubescence, obscuring integument. Lateral portions of prothorax and prosternum reddish with chalk white pubescence. Elytra with longitudinal stripe, wide, white chalk pubescence from base to apex, narrowed medially and with reddish stripe beginning at humerus, widening before middle, but not reaching suture. Lower portion of body reddish, without spots of compact pubescence, but covered with white pubescence.

Measurements holotype female. Total length, 20.5; length of prothorax, 3.7; greatest width of prothorax, 4.3 ; length of elytron, 16.5; humeral width, 6.4.

Type material. Female holotype, Peru, Cuzco: Kosñipata Vy San Pedro (1368 m), 11-15.XI.2009, Heppner, Carrera \& Huamani leg. (ACMS).

\section{Calliini}

\section{Amucallia carbonaria sp. nov.}

Fig. 7

Head black; frons reddish-black, sparsely pubescent. Indistinct white pubescent stripe on vertex. Antennae black; antennomeres IX-X white, the later with black hairs on apical half; antennomere XI white at base and gradually darker toward apex. Flagellomeres somewhat thickened. Prothorax black, rounded at sides, widest at middle, without lateral spine. Each side of pronotum with more or less conspicuous, reddish-black area of moderate dimensions; pronotal surface regularly convex. Lateral portions of prothorax reddish on boundary with prosternum. Prosternum reddish. Mesosternum, and metasternum black. Scutellum black. Elytra black, pubescent. Procoxae, mesocoxae, profemora, and mesofemora reddish. Metafemora reddish, apical third black. Tibiae and tarsi black. Urosternites black.

Measurements holotype female. Total length, 5.6; length of prothorax, 1.0; greatest width of prothorax, 1.2; length of elytron, 4.1; humeral width, 1.6.

Type material. Female holotype, French Guyana, Guyane: Roura (21 km SE on Kaw road, $\left.04^{\circ} 36,115^{\prime} \mathrm{S}, 52^{\circ} 15,972^{\prime} \mathrm{W}\right)$ 67.II.2010, J.E. Eger leg., MV light (ACMS).

Etymology. Latin, carbonarius = coal; alluding to the general coloration.

Remarks. Amucallia was established by GaLILEO \& MarTins (2008: 7) for A. hovorei, a species originally described from Panama. They noticed that Amucallia is similar to Callia Audinet-Serville, 1835, differing by the prothotax without lateral spine. GaLILEo \& Martins (2010) described three additional species of Amucallia from Colombia and Venezuela and illustrated the four species of the genus. Amucallia carbonaria sp. nov. differs from all other species by the black coloration of the dorsal surface. In the remaining species the prothorax is reddish or yellowish, and the elytra are not black. 

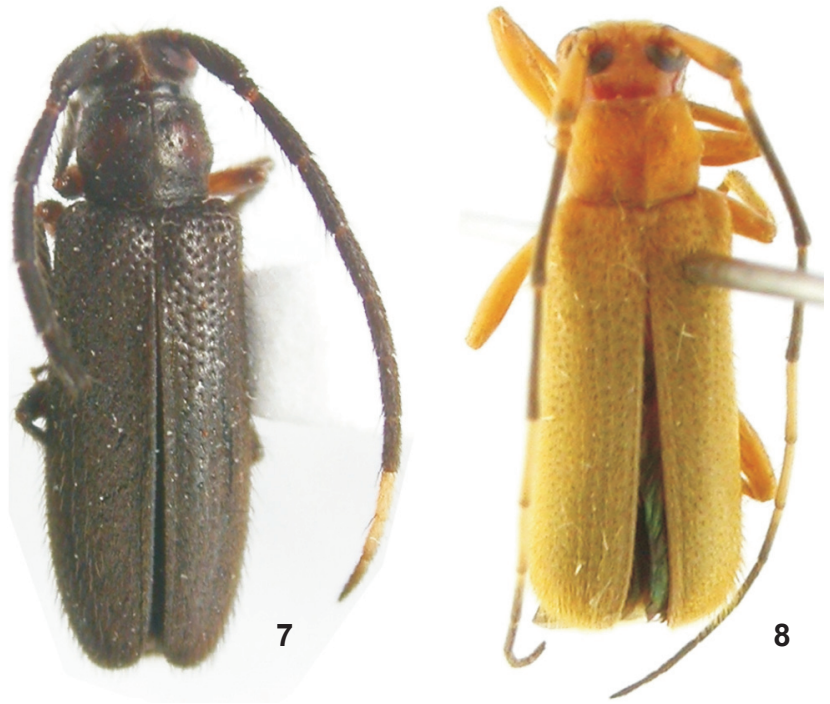

Figures 7-8. (7) Amucallia carbonaria sp. nov., holotype female, total length, $5.6 \mathrm{~mm}$; (8) Amucallia citrina sp. nov., holotype female, total length, $6.8 \mathrm{~mm}$.

\section{Amucallia citrina sp. nov. \\ Fig. 8}

Head orange. Frons with very sparse pubescence. Upper ocular lobes wide, with nine rows of ommatidia, separated by little more than the width of a lobe. Antennae (female) reaching apices of elytra at apex of antennomere VII. Scape orange with brownish apex. Pedicel orange. Antennomeres III and IV black with narrow, orangish basal ring, sparsely fringed at inner side; V and VI (except for apical ring brownish) whitishyellow; VII black, with basal yellowish ring; VIII-XI black. Prothorax orange. Pronotal pubescence yellowish, not apparent in large area on each side of base (when insect's head faces the light source). Lateral portions of prothorax orange and pubescent. Elytra yellowish. Elytral punctuation conspicuous, dorsally organized in longitudinal rows; pubescence fine, yellowish, interspersed with longer hairs, also yellowish. Pro- and mesocoxae yellowish. Femora, tibiae, and tarsi yellow-orange. Ventral surface of body orange and pubescent.

Measurements holotype female. Total length, 6.8; length of prothorax, 1.2; greatest width of prothorax, 1.4; length of elytron, 4.9; humeral width, 2.0.

Type material. Holotype female, Guiana, District Kartabo Point: Mazaruni-Potaro, 27.XII.1983, Earthwatch Research Expedition: W. Steiner, J. Byrd, J. Hill \& F. Holtzclaw leg., "Malaise trap at edge of secondary forest and farmed field" (USNM).

Etymology. Grego, citrus = citric; referring to the general coloration.

Remarks. Amucallia citrina sp. nov. differs from most other species of Amucallia in having the prothorax and elytra concolorous. Amucallia miranda Galileo \& Martins, 2010, from Venezuela (Miranda), also has this feature. From A. miranda, $A$. citrina differs as follows: scape reddish with black apex; pedicel reddish; antennomeres IV and V white; tegument of elytra orange; and metathoracic sterna and urosternites orange. In $A$. miranda, the antennae, base of elytra, thoracic sterna, and urosternites are black.

\section{ACKNOWLEDGMENTS}

We thank James Wappes (ACMS) and Carlos Flechtmann (UNESP) for sending material for study; Antonio Santos-Silva (MZUSP) for taking the photographs; and Conselho Nacional de Desenvolvimento Científico e Tecnológico (CNPq, processes 304861/2006-5 and 301467/2009-9).

\section{LITERATURE CITED}

Galileo, M.H.M. \& U.R. Martins. 2007. Novas espécies de Neocorini e Pteropliini (Coleoptera, Cerambycidae) da América do Sul. Revista Brasileira de Zoologia 24: 203-204.

Galileo, M.H.M. \& U.R. Martins. 2008. Novos táxons de Lamiinae (Cerambycidae) Neotropicais. Les Cahiers Magellanes 73: $1-9$

Galileo, M.H.M. \& U. Martins. 2010. Novas espécies de Amucallia e de Mimolaia do norte da América do Sul (Cerambycidae, Lamiinae, Calliini). Les Cahiers Magellanes 109: 1-8.

Martins, U.R. 1999. Tribo Eburiini, p. 119-391. In: Cerambycidae sul-americanos (Coleoptera). São Paulo, Sociedade Brasileira de Entomologia, vol. 3, V+418p.

MarTins, U.R. 2003. Tribo Sydacini, p. 203-213. In: Cerambycidae sul-americanos (Coleoptera). São Paulo, Sociedade Brasileira de Entomologia, vol. 6, VII+232p.

Submitted: 27.VI.2012; Accepted: 01.IX.2012.

Editorial responsibility: Gabriel L.F. Mejdalani 